\title{
Seasonal change monitoring and mapping of coastal vegetation types along Midnapur-Balasore Coast, Bay of Bengal using multi-temporal landsat data
}

\author{
Adarsa Jana $^{1,2} \cdot$ Sabyasachi Maiti ${ }^{2} \cdot$ Arkoprovo Biswas $^{3}$
}

Received: 23 November 2015/ Accepted: 24 November 2015/Published online: 20 December 2015

(C) Springer International Publishing Switzerland 2015

\begin{abstract}
The present study highlights the application of satellite remote sensing in seasonal change monitoring and mapping of coastal vegetation types along MidnapurBalasore coast, Bay of Bengal, using multi-temporal satellite images of Landsat ETM+ of 2000, 2001 and 2002 of pre-monsoon and post-monsoon seasons. Two types of image analysis techniques were applied in this study to identify different species of coastal vegetations, health and their areal extent. RGB-NDVI was computed to detect and monitor the changes of vegetation health during pre and post-monsoon period. Another technique is supervised digital classification was used for mapping of different coastal vegetations and to determine their spatial extent of the study area. Five major coastal vegetation types were delineated using satellite data viz., dune vegetation, mangroves, salt marsh, agricultural lands and other vegetations. An attempt has been made to analyze seasonal change monitoring and mapping of different coastal vegetations communities including mangroves, salt marsh, and dune
\end{abstract}

Adarsa Jana

adarsa.rsiitkgp@gmail.com

Sabyasachi Maiti

maiti@gg.iitkgp.ernet.in

Arkoprovo Biswas

arkoprovo@gmail.com

1 NRDMS Centre, Office of the District Magistrate, Administrative Building, Purba Medinipur, Tamluk, WB 721636, India

2 Department of Geology and Geophysics, Indian Institute of Technology Kharagpur, Kharagpur, WB 721302, India

3 Department of Earth and Environmental Sciences, Indian Institute of Science Education and Research Bhopal, Bhopal, MP 462066, India vegetation from 2000 to 2002 using Landsat 7 ETM+ data. From 2000 to 2002 it is observed that the areal extent of salt marsh and dune vegetation is changed seasonally along each littoral cell. It is increased during post-monsoon season and decrease during pre-monsoon season. In this period, the gain of 704.34 ha area of salt marsh and 2153.88 ha area of dune vegetations cover was noticed. During post-monsoon period the mangrove vegetation covers along all littoral cells have increased this may be due to supply of huge amount of sediment and increase of salinity condition after monsoon. But over the entire 3 years period from pre-monsoon 2000 to post-monsoon 2002 the net change was negative, which was quantified as $61.83 \mathrm{ha}$. The depletion of mangroves may be due to high anthropogenic pressure, commercial aquaculture, highly eroding nature of the coast and tidal activities. The NDVI derived from ETM+ images provide useful information to monitor coastal vegetation changes, especially the natural plants growing on sand dunes, mangroves and salt marsh vegetations. The analysis of NDVI variations showed the qualitative information about the vegetation. On the other hand classified image provide quantitative information about the coastal vegetation.

Keywords Coastal vegetation - NDVI (normalized differential vegetation index) $\cdot$ RGB-NDVI $\cdot$ Remote sensing $\cdot$ Seasonal change $\cdot$ Midnapur-Balasore coast

\section{Introduction}

The interface between land and sea, the coast is unique geologic, ecological and biological domain of vital importance to an amazing selection of terrestrial and aquatic life forms including manhood (Beatley et al. 2002). 
The coastal ecosystem is highly delicate because of the multivariate energetically active and pulsatory tectonic and geomorphic processes (Chatterjee et al. 2008). Coastal vegetations are highly adapted halophytes occupying the intertidal zone in estuaries, lagoons and coastal mud flats in tropical and subtropical regions of the world. These are socio-economically important ecosystems, especially for the habitants of coastal regions and also safeguard the coastal environments. Coastal vegetations are undergoing constant changes seasonal, short-term and long-term due to its dynamic nature itself and to a greater extent through various natural and biotic influences (Reddy and Roy 2008). As coastal vegetations are sensitive to even minor transitions in coastal conditions (e.g., altered drainage patterns, saltwater intrusion, accretion or erosion in response to sea level variations), changes in the zonation of these ecosystems are often indicative of broader scale changes and associated impacts in coastal regions (Chatterjee et al. 2008).

Up-to-date information on the status of coastal vegetations over time is pre-requisite for a sustainable management of coastal vegetations and also coastal regions. Traditional field surveys inside the swampy areas are extremely difficult. Remote sensing and Geographic Information System (GIS) technique provides fast, synoptic, multi-spectral and repetitive coverage which is very useful to detect such changes continually over time (Ricketts 1992; Hashiba et al. 2000; Reddy and Roy 2008; Jana et al. 2014). Global Positioning Systems (GPS) aid in the collection of ground data and processing of remotely sensed imagery.

The main objective of this study was to identify different categories of coastal vegetation and to detect, assess and monitor the changes in their spatial extent including their health in pre- monsoon and post-monsoon season using remote sensing and GIS.

\section{Study area}

The study was carried on the Midnapur-Balasore coast extending from Rasulpur River to Panchpara Inlet on the eastern coast India (Fig 1). The western end of the study area is bounded by Panchpara Inlet in Balasore district of Orissa, while Rasulpur River in East Midnapur district of West Bengal forms the eastern boundary. Geographically it is located between latitudes $21^{\circ} 30^{\prime} 0^{\prime \prime} \mathrm{N}-21^{\circ} 48^{\prime} 0^{\prime \prime} \mathrm{N}$ and longitudes $87^{\circ} 12^{\prime} 0^{\prime \prime} \mathrm{E}-87^{\circ} 54^{\prime} 0^{\prime \prime} \mathrm{E}$. The area falls within subtropical humid climate with three distinct seasons viz. pre-monsoon (March-June), monsoon (July-Oct), and post-monsoon (Nov-Feb). The maximum daily temperature ranges between 26.9 and $36.8{ }^{\circ} \mathrm{C}$ while the minimum temperature lies in between 5.7 and $24.7{ }^{\circ} \mathrm{C}$. The range of average annual rainfall is $1192-1956 \mathrm{~mm}$ with relative humidity varying between 60 and $90 \%$ (GSI 1995). It is a part of low-lying, mesotidal tropical coast of Bay of Bengal. Topographically, this area is generally flat land with some undulations at some places. The geomorphic divisions, viz., beach, active dunes, mud flats, chenier plains etc., of the present study area have developed within the last 6000 years (Paul 2002; Dey et al. 2005). The surface elevation of the area ranges between 0 and $20 \mathrm{~m}$. Development of soil profile is very poor in the Midnapur-Balasore coastal tract. On the present day inter tidal flats, drained antisol with high salinity soil is found. Well drained sandy soils, sandy loam soils and thin vencer of antisol to inceptisol, saline soils found on the beach front, coastal dune and older dune complex areas, respectively. On the clayey or ancient inter tidal flat agricultural supported soil that is antisol to inceptisol is found (GSI 1995).

Midnapur-Balasore coastal zone, located in the eastern part of India is an important sea resort and thickly populated zone of West Bengal and Orissa, have been experiencing coastal erosion, tidal inundation, salinization for several decades. This coastal area has gained considerable commercial importance in the socio-economically development of the region. It is an ecologically sensitive coastal region. In this context the study of coastal vegetation is highly necessary and revegetation along the entire coast would an alternative and long term effective approach to check erosion and for sustainable development of the coast.

\section{Materials and methods}

\section{Data used}

The study was carried out using multi-temporal satellite images of Landsat ETM+ (Enhanced Thematic Mapper Plus) of 2000, 2001 and 2002 (path 139 and row 45) of both pre and post monsoon seasons. The orthorectified Landsat ETM+ data was downloaded from USGS data archive (http://www.eros.usgs.gov). Landsat ETM+ data from 2000 to 2002 were selected as it was freely available. However the datasets beyond 2002 has a problem of linedrops or data gaps. Consequently, these have restricted accurate identification of the areas falling within these data gaps. Different available techniques (Maxwell et al. 2007) for line-drop correction are found to be unsuitable for dynamic coastal zones. Pre and post-monsoon seasons were considered to understand the seasonal change in coastal vegetations. Pre to post-monsoon period is called as devastating period because during this period coastal region is greatly affected by floods, cyclones, storms and others environmental hazards. Alternatively, post to premonsoon period is called as recovery period. In this period, a huge amount of sediment is accumulated in the coastal 
Fig. 1 Location map of the study area

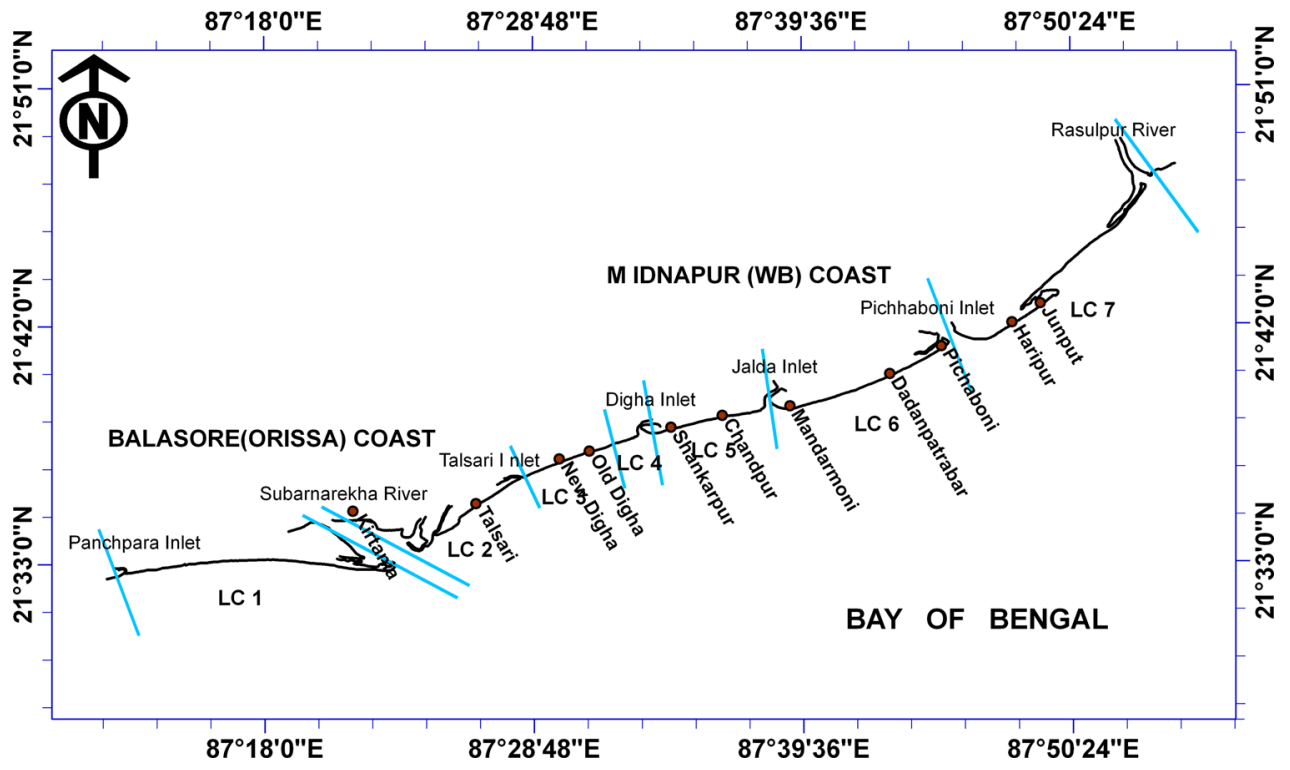

belt containing different kinds of minerals and overall increase in salinity. The tidal conditions during data acquisition were also considered for minimizing tidal influences. During low-tide condition maximum land and the vegetations in intertidal areas are exposed. In the present study, low-tide slacking conditions of data acquisition were considered during both pre and post-monsoon seasons. However in few cases, data of rising period were used. The images were processed using the ERDAS Imagine 8.5 software. Table 1 provides details of the satellite data used in this study.

\section{Image analysis}

In vegetation monitoring and mapping, infrared wavelength $0.8-1.4 \mu \mathrm{m}$ is important (Lillesand and Kiefer 1994). Due to absorption by pigments of vegetation, the highest reflectance occurs in NIR region. Infrared energy reflects well off of healthy vegetation so the infrared bands can be useful in detecting changes in vegetation (Table 2).

Two types of image analysis techniques were applied in this study to identify different species of coastal vegetations, health and their areal extent: RGB-NDVI and supervised classification.

\section{$R g b-n d v i$}

Vegetation indices (VI) have long been used in remote sensing for monitoring temporal changes associated with vegetation (Lyon et al. 1998). Normalized Difference Vegetation Index (NDVI) has been used by several authors as reliable estimates of vegetation health (Campbell 2002). NDVI can be calculated as a ratio of red and the NIR bands of a sensor system, NDVI $=($ Infrared - Red $) /($ Infrared + Red). It ranges from -1 to +1 ; healthy vegetation is represented by high NDVI values between 0.1 and 1 . Conversely, non- vegetated surfaces such as water bodies yield negative values, which are closest to 0 due to high reflectance in both the visible (Red) and NIR (Lillesand and Kiefer 1994).

Several methods apply for change detection monitoring by using NDVI classification (Fuller 1998). Among those techniques, RGB-NDVI classification is the fastest and easiest method to assess the change of the vegetation

Table 1 List of satellite data used in this study with their acquisition date and time and tidal heights during data acquisitions

\begin{tabular}{lllll}
\hline Satellite images & Date of acquisition & Time of acquisition $(\mathrm{GMT}+5: 30)$ & Tidal height (m) & Seasonal condition \\
\hline Landsat ETM+ & March 29, 2000 & $10: 00: 06$ & 2.29 & Pre-monsoon \\
& November 8, 2000 & $9: 57: 52$ & 3.27 & Post-monsoon \\
Landsat ETM+ & May 3, 2001 & $9: 57: 38$ & 2.8 & Pre-monsoon \\
Landsat ETM+ & October 26, 2001 & $9: 55: 52$ & 2.83 & Post-monsoon \\
& May 22, 2002 & $9: 56: 16$ & 2.75 & Pre-monsoon \\
& October 29, 2002 & $9: 55: 21$ & 2.48 & Post-monsoon \\
\hline
\end{tabular}


Table 2 Littoral cell wise areal extent of coastal vegetation, coastal vegetation observed in the field and geomorphological features (area in ha)

\begin{tabular}{|c|c|c|c|c|c|c|c|c|c|}
\hline \multirow{2}{*}{$\begin{array}{l}\text { Littoral } \\
\text { cell } \\
\text { (LC) }\end{array}$} & \multirow{2}{*}{$\begin{array}{l}\text { Coastal } \\
\text { vegetations }\end{array}$} & \multicolumn{2}{|l|}{2000} & \multicolumn{2}{|l|}{2001} & \multicolumn{2}{|l|}{2002} & \multirow{2}{*}{$\begin{array}{l}\text { Types of coastal } \\
\text { vegetation } \\
\text { observed in the } \\
\text { field }\end{array}$} & \multirow[t]{2}{*}{ Geomorphological feature } \\
\hline & & $\begin{array}{l}\text { Pre- } \\
\text { monsoon }\end{array}$ & $\begin{array}{l}\text { Post- } \\
\text { monsoon }\end{array}$ & $\begin{array}{l}\text { Pre- } \\
\text { monsoon }\end{array}$ & $\begin{array}{l}\text { Pre- } \\
\text { monsoon }\end{array}$ & $\begin{array}{l}\text { Post- } \\
\text { monsoon }\end{array}$ & $\begin{array}{l}\text { Pre- } \\
\text { monsoon }\end{array}$ & & \\
\hline \multirow[t]{3}{*}{ LC1 } & $\begin{array}{l}\text { Mixed } \\
\text { mangroves }\end{array}$ & 4.59 & 38.25 & 0.81 & 12.69 & 0.18 & 10.71 & $\begin{array}{l}\text { Avicennia sp., } \\
\text { Pandanus sp. }\end{array}$ & \multirow{3}{*}{$\begin{array}{l}\text { Tidal inlet, tidal creek, } \\
\text { spit, dune (casuarinas), } \\
\text { mangroves }\end{array}$} \\
\hline & Salt marsh & 69.93 & 44.19 & 23.22 & 74.52 & 139.5 & 166.23 & $\begin{array}{l}\text { Salicornia sp., } \\
\text { Portulaca sp., }\end{array}$ & \\
\hline & $\begin{array}{l}\text { Dune } \\
\text { vegetations }\end{array}$ & 76.59 & 305.01 & 123.84 & 340.02 & 167.67 & 342 & $\begin{array}{l}\text { Casuarina } \\
\text { equisetifolia, } \\
\text { Pandanus sp., } \\
\text { Anacardium } \\
\text { occidentale. }\end{array}$ & \\
\hline \multirow[t]{3}{*}{ LC2 } & $\begin{array}{l}\text { Mixed } \\
\text { mangroves }\end{array}$ & 176.85 & 228.33 & 201.69 & 209.88 & 167.94 & 73.62 & $\begin{array}{l}\text { Avicennia sp., } \\
\text { Rhizophora sp. }\end{array}$ & \multirow{3}{*}{$\begin{array}{l}\text { Tidal inlet, tidal creek, } \\
\text { paleo dune, tidal flat, } \\
\text { barrier bar, elevated } \\
\text { berm, dune (casuarinas), } \\
\text { mangroves }\end{array}$} \\
\hline & Salt marsh & 128.7 & 317.97 & 101.61 & 441.54 & 406.62 & 566.73 & - & \\
\hline & $\begin{array}{l}\text { Dune } \\
\text { vegetations }\end{array}$ & 103.05 & 799.38 & 300.33 & 709.65 & 284.76 & 661.77 & - & \\
\hline \multirow[t]{3}{*}{ LC3 } & $\begin{array}{l}\text { Mixed } \\
\text { mangroves }\end{array}$ & 20.16 & 65.43 & 5.22 & 30.78 & 3.6 & 14.31 & - & \multirow[t]{3}{*}{$\begin{array}{l}\text { Tidal inlet, barrier bar, } \\
\text { dune (casuarinas) }\end{array}$} \\
\hline & Salt marsh & 3.51 & 25.02 & 30.96 & 21.24 & 9.81 & 22.59 & - & \\
\hline & $\begin{array}{l}\text { Dune } \\
\text { vegetations }\end{array}$ & 109.17 & 501.3 & 0 & 374.4 & 124.92 & 389.34 & - & \\
\hline \multirow[t]{3}{*}{ LC4 } & $\begin{array}{l}\text { Mixed } \\
\text { mangroves }\end{array}$ & 18.27 & 31.23 & 2.07 & 26.46 & 0 & 10.26 & - & \multirow{3}{*}{$\begin{array}{l}\text { Tidal inlet, barrier bar, } \\
\text { paleo dune, dune } \\
\text { (casuarinas) }\end{array}$} \\
\hline & Salt marsh & 42.3 & 55.44 & 61.56 & 44.19 & 62.46 & 66.96 & - & \\
\hline & $\begin{array}{l}\text { Dune } \\
\text { vegetations }\end{array}$ & 124.74 & 329.04 & 213.75 & 311.49 & 204.39 & 407.43 & - & \\
\hline \multirow[t]{3}{*}{ LC5 } & $\begin{array}{l}\text { Mixed } \\
\text { mangroves }\end{array}$ & 4.68 & 13.14 & 0 & 13.5 & 1.17 & 7.11 & Pandanus sp. & \multirow[t]{3}{*}{$\begin{array}{l}\text { Tidal inlet, mud flat, spit, } \\
\text { paleo dune, dune (keya) }\end{array}$} \\
\hline & Salt marsh & 98.55 & 143.19 & 99.63 & 103.68 & 181.89 & 128.25 & $\begin{array}{l}\text { Salicornia sp., } \\
\text { Portulaca sp., } \\
\text { Spartina sp., } \\
\text { Atriplex sp. }\end{array}$ & \\
\hline & $\begin{array}{l}\text { Dune } \\
\text { vegetations }\end{array}$ & 37.71 & 179.28 & 67.57 & 138.33 & 80.91 & 206.91 & $\begin{array}{l}\text { Casuarina } \\
\text { equisetifolia, } \\
\text { Ipomoea biloba, } \\
\text { Spinifex sp., } \\
\text { Serenoa repens. }\end{array}$ & \\
\hline \multirow[t]{3}{*}{ LC6 } & $\begin{array}{l}\text { Mixed } \\
\text { mangroves }\end{array}$ & 6.03 & 64.89 & 0.54 & 62.82 & 0.9 & 52.74 & - & \multirow{3}{*}{$\begin{array}{l}\text { Tidal inlet, tidal creek, } \\
\text { mud flat, tidal flat, spit, } \\
\text { paleo dune }\end{array}$} \\
\hline & Salt marsh & 19.98 & 81.45 & 56.97 & 82.26 & 15.66 & 116.55 & $\begin{array}{l}\text { Salicornia sp., } \\
\text { Portulaca sp., } \\
\text { Spartina sp., } \\
\text { Atriplex sp. }\end{array}$ & \\
\hline & $\begin{array}{l}\text { Dune } \\
\text { vegetations }\end{array}$ & 247.86 & 903.96 & 246.15 & 585.54 & 334.26 & 845.55 & $\begin{array}{l}\text { Casuarina } \\
\text { equisetifolia. }\end{array}$ & \\
\hline
\end{tabular}

(Sader and Winne 1992). In this method the changed features are represented in the form of RGB color and the features which remain constant are represented in grey value.

In this study NDVI was done to asses, detect and monitor the health and changes of vegetation occur throughout the years. For this work three satellite images of pre-monsoon and three images of post-monsoon were considered and then NDVI were done for each of the images. Then three images of pre-monsoon and considerably three images of post-monsoon were stacked and RGBNDVI was produced. 


\section{Supervised classification}

Supervised digital classification method is used for mapping of coastal vegetation and other inland vegetation of the study area. This has been the most frequent method for remotely sensed data classification. In supervised classification the samples of known identity were used to classify pixels of unknown identity. Training sites in the images are generated to represent the typical spectral information of the classes (dune vegetation, mixed mangrove, salt marsh, agricultural lands and other vegetation). After the selection of training sites, the classification was run on the image using Maximum likelihood classifier in ERDAS Imagine 8.5 software.

\section{Results and discussion}

\section{Results from RGB-NDVI techniques}

In the present study NDVI have been generated of each of the images. Total six NDVI images of pre and post-monsoon seasons for 3 years have been stacked. Different combination of RGB-NDVI had been generated from those stacked layers.

The RGB-NDVI information of pre-monsoon images of 2000 is represented as red color, post-monsoon images of 2000 as green color and pre-monsoon images of 2001 as blue color, respectively (Fig. 2a). This RGB-NDVI combination shows mangroves and dune vegetations as green patches which indicates the health of the mangrove and dune vegetation is increased during post-monsoon period. On the other hand, salt marsh vegetation is seen as blue patches that indicate the health of the salt marsh vegetation are increased in the last pre-monsoon period. Considerably, other two figures (Fig. 2b, c) also show the similar information.

In RGB-NDVI, we considered pre to post-monsoon and post to pre-monsoon images separately. During these two different periods coastal land is changed. Pre to postmonsoon period is called as devastating period because during this period coastal region is greatly affected by flood, cyclones, storms and others environmental hazards. Alternatively, post to pre-monsoon period is called as recovery period. In this period, a huge amount of sediment is accumulated in the coastal belt containing different kinds of minerals and salinity is also increases. This has great impact on coastal vegetations. Due to high salinity the growth and health of the black mangrove i.e. Avicennia sp. is increased. The health of the dune vegetation, sand-loving grasses or creepers like ipomoea is affected by rainfall and salt spray which enhance the growth of the dune vegetation. The health of the salt marsh is increased after post-monsoon and it reaches its maximum during premonsoon season because it is less frequently inundated by the tidal water than post-monsoon. RGB-NDVI shows that during post-monsoon, the health of vegetation is better than compare to other pre-monsoon seasons.

\section{Results from classification techniques}

The low-lying, mesotidal tropical coastal plains of Midnapur-Balasore, which lie on the South Bengal basin, are covered by alluvium of very thick Tertiary sediments. The gentle sloping with clay loam and sandy loam soils and favorable geomorphic terrain, predominantly support for the growth of coastal vegetations. Five major coastal vegetation types from 2000, 2001 and 2002 images of both pre and post-monsoon periods were delineated using satellite data viz., dune vegetation, mixed mangroves, salt marsh, agricultural lands and other vegetations (Figs. 3, 4, $5,6,7,8)$.

The changes in coastal vegetation especially mixed mangroves, salt marsh and dune vegetations have been assessed and their details were given in Table 3 . There were seasonal variations (2000 Pre-monsoon to 2000 Postmonsoon, 2001 Pre-monsoon to 2001 Post-monsoon and 2002 Pre-monsoon to 2002 Post-monsoon), both positive and negative, those are related mainly to the dynamics of the natural vegetation structure, tidal activities, erosion, accretion, environmental events and anthropogenic influences.

During post-monsoon period the mixed mangrove vegetations covers along all littoral cells have increased this may be due to supply of huge amount of sediment and increase of salinity condition after monsoon. But over the entire 3 years period from pre-monsoon 2000 to postmonsoon the net change was negative, which was quantified as 61.83 ha (Table 4). The depletion of mixed mangroves vegetation may be due to high anthropogenic pressure, commercial aquaculture, highly eroding nature of the coast and tidal activities. The evidences of decomposed root and shoots, buried under the beach sand now, bare evidences that merely 100 years ago mangrove cover quite extensive in this coastal tract. From 2000 to 2002 it is observed that the areal extent of salt marsh and dune vegetation is changed seasonally along each littoral cell. It is increased during post-monsoon season and decrease during pre-monsoon season. In this period, the gain of 704.34 ha area of salt marsh and 2153.88 ha area of dune vegetations cover was noticed (Table 4). As the frequency of the tidal water increases during the post-monsoon season so that the salinity in the lower marsh region is also increases. As a result the development of the salt marsh 
Fig. 2 a RGB-NDVI map showing vegetation health during 2000-2001. b RGBNDVI map showing vegetation health during 2001-2002. c RGB-NDVI map showing vegetation health during 2002
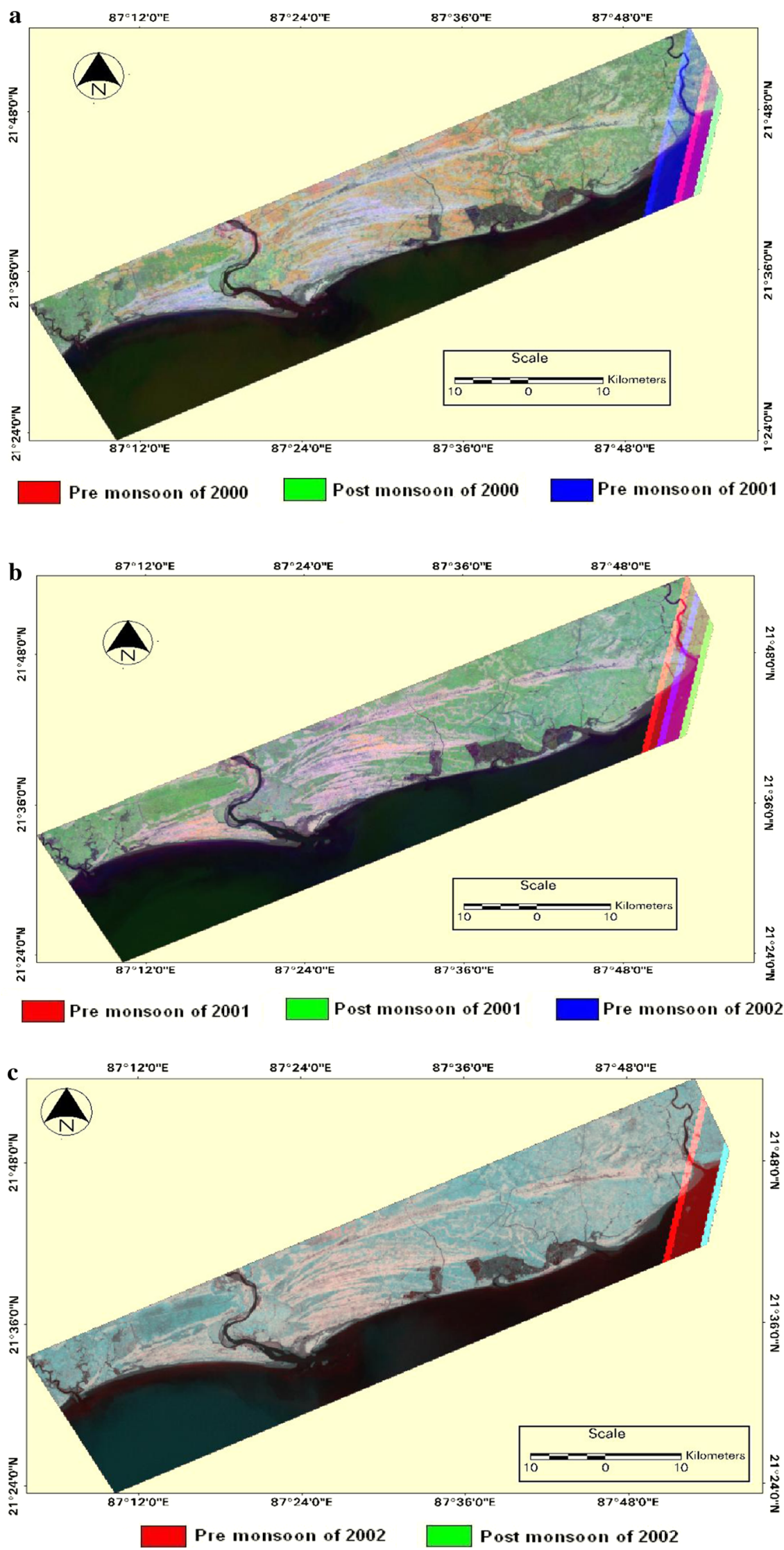


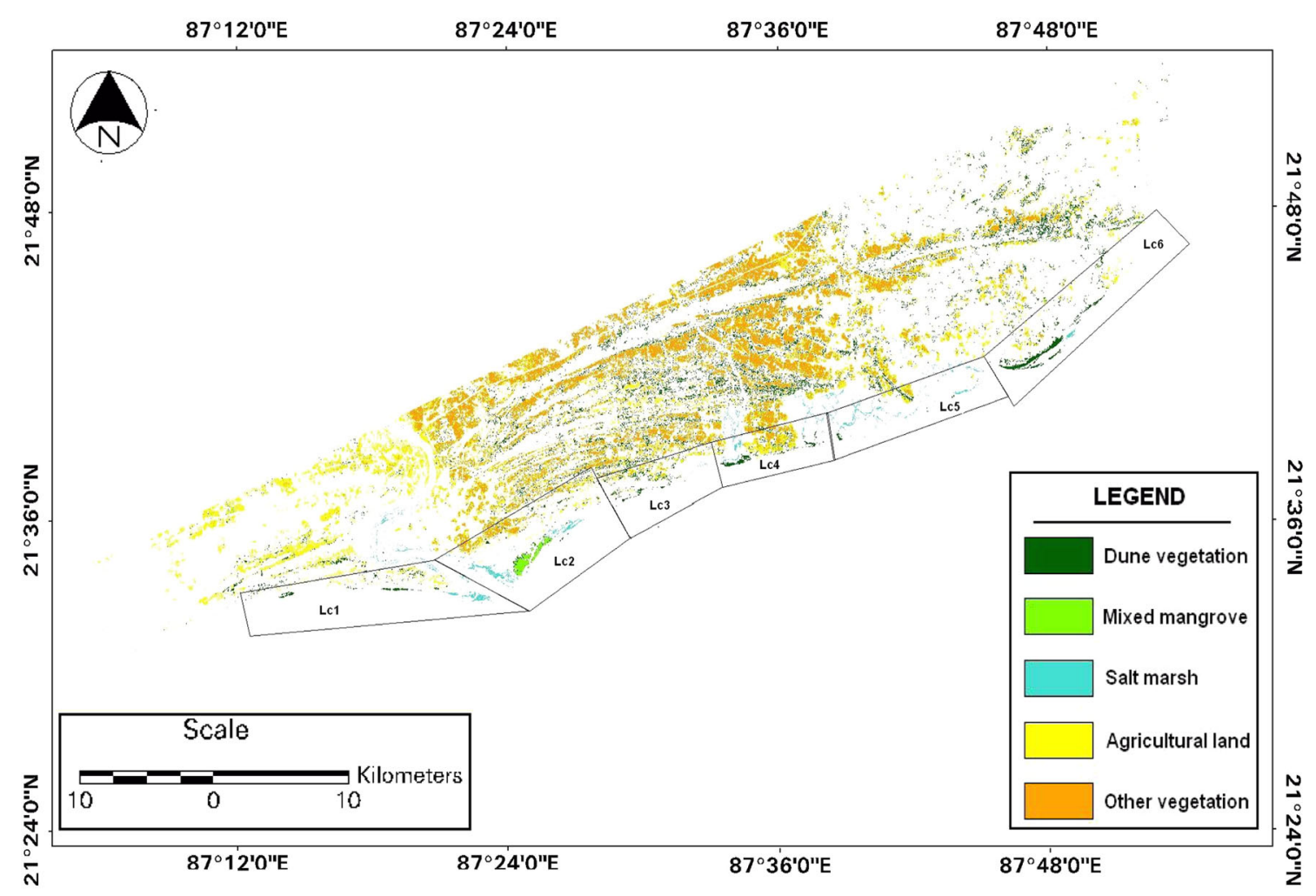

Fig. 3 Coastal vegetation map showing pre-monsoon information of 2000

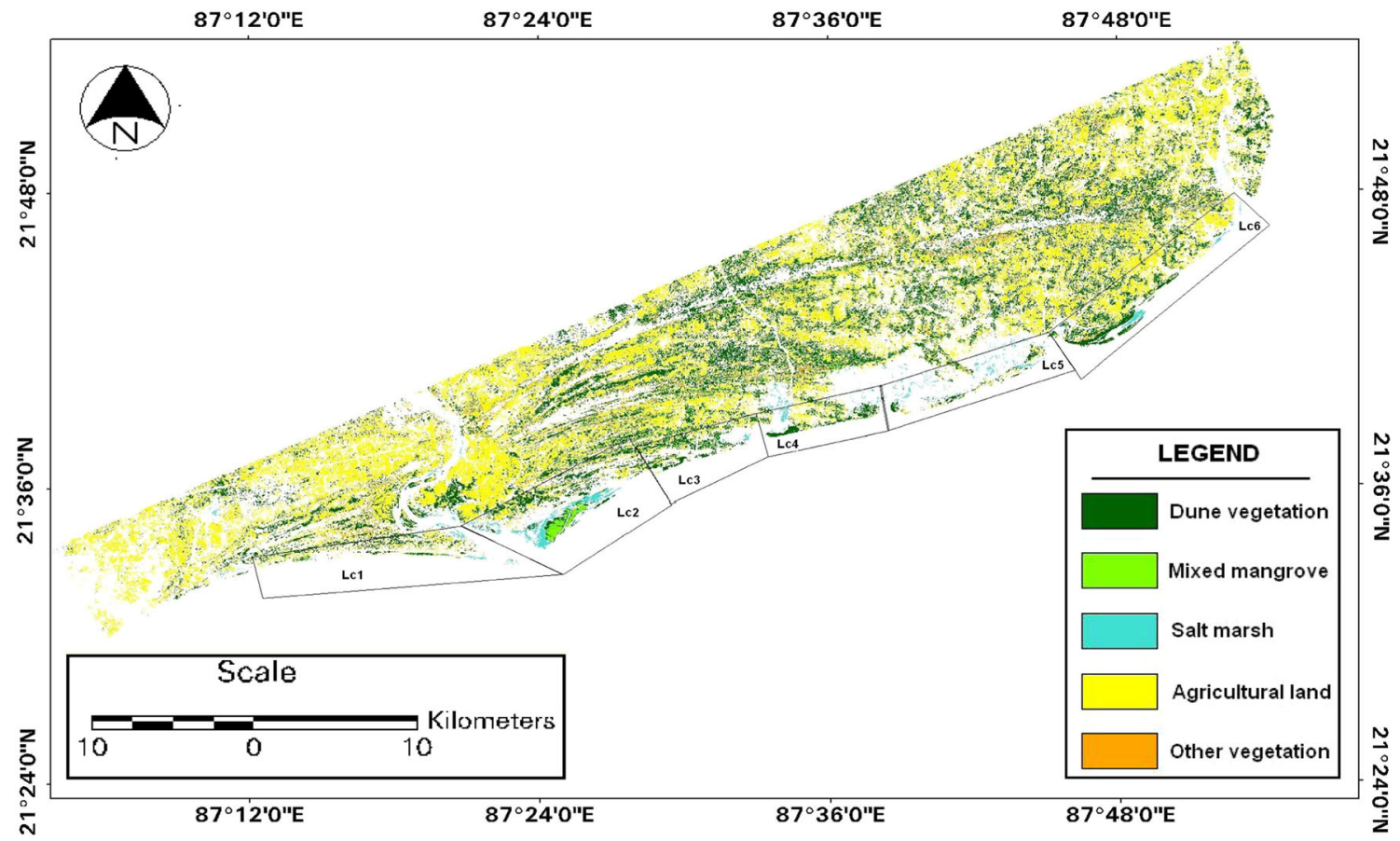

Fig. 4 Coastal vegetation map showing post-monsoon information of 2000

vegetation increases after post-monsoon season as shown in Table 5. The dominant species is Casuarina equisetifolia, its spatial distribution is not generally changed but other dune creepers that is sand- loving grasses are generally increased in huge amount during the post-monsoon period this may be due to salinity change during post-monsoon season. 


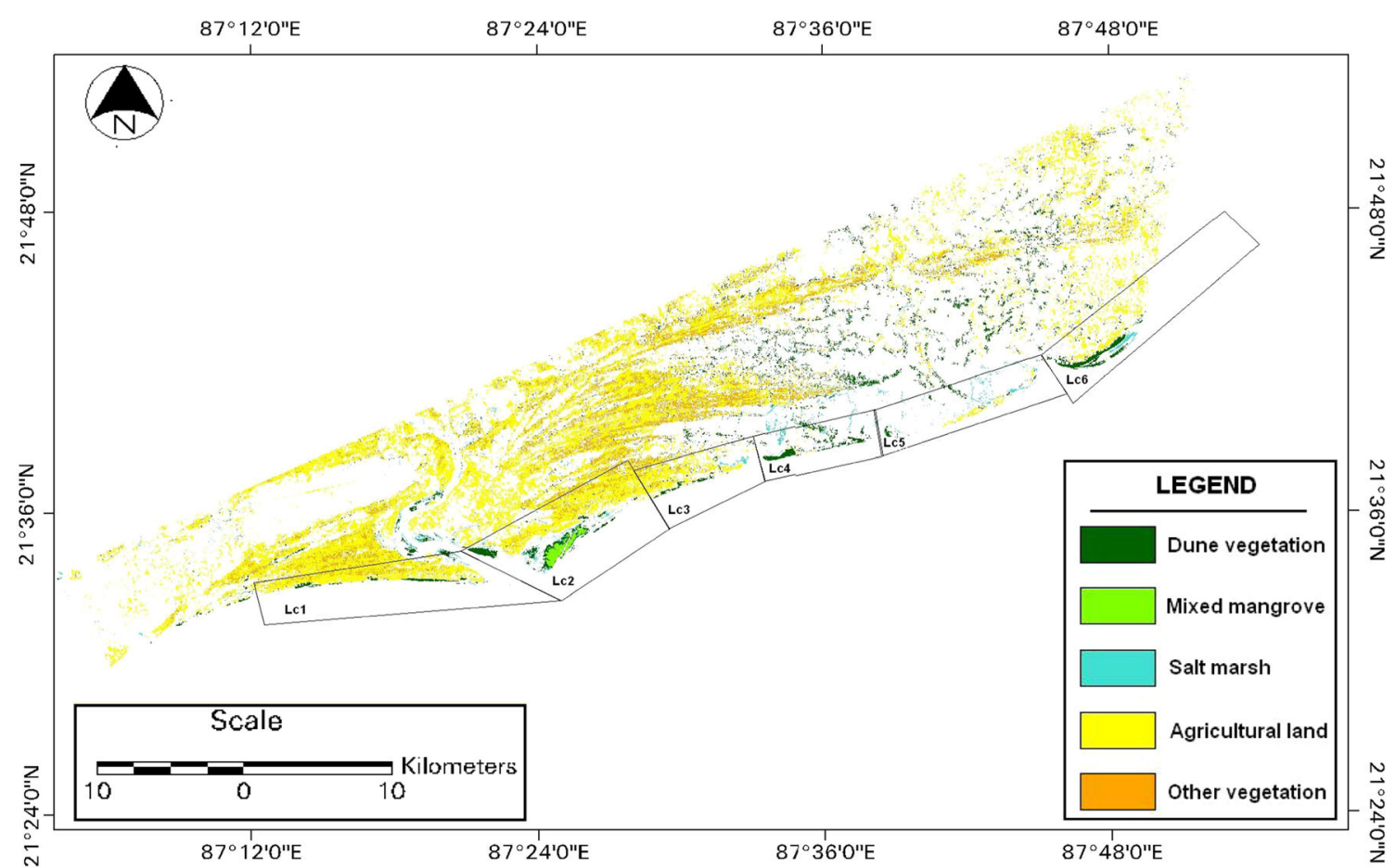

Fig. 5 Coastal vegetation map showing pre-monsoon information of 2001

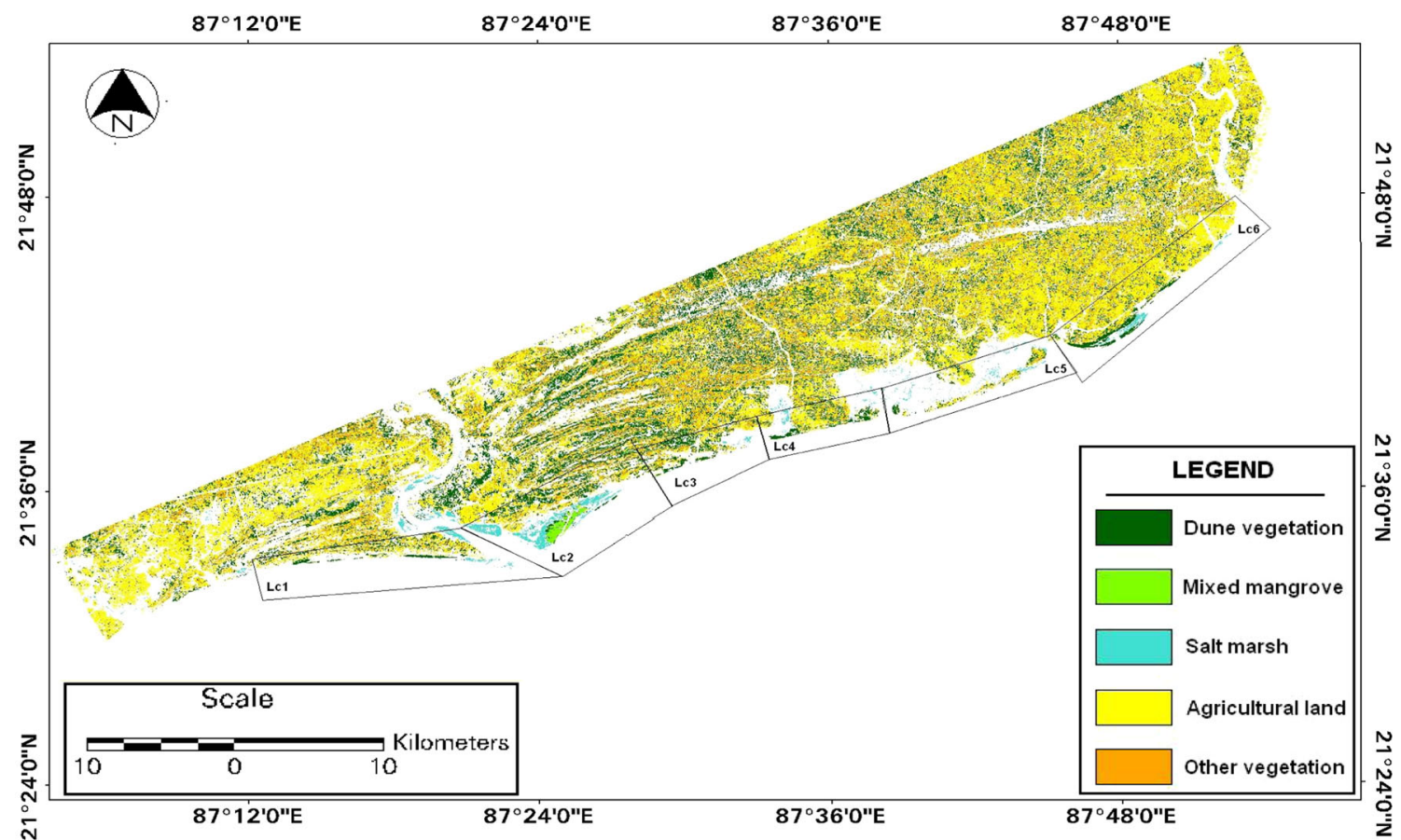

Fig. 6 Coastal vegetation map showing post-monsoon information of 2001

\section{Results from field surveys}

Field surveys were carried out along $113.5 \mathrm{~km}$ long coastal stretches to study the coastal vegetation, identify various species and other land cover. False colour composition satellite images and Survey of India (SOI) topographical maps (73O/2, 73O/6, 73O/10, 73O/13 and 73O/14) of 1973 were used to collect ground information. Ground truth data 


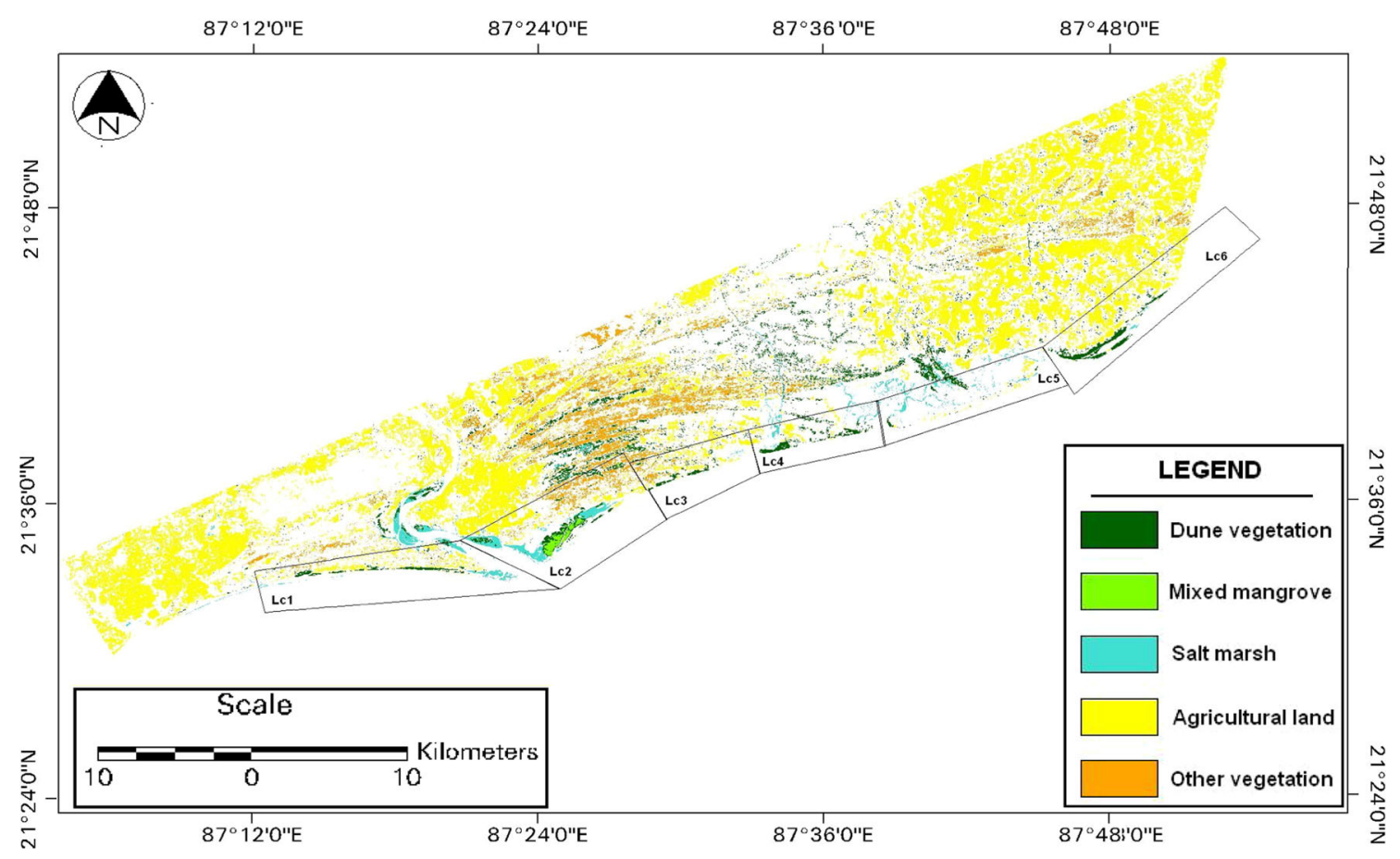

Fig. 7 Coastal vegetation map showing pre-monsoon information of 2002

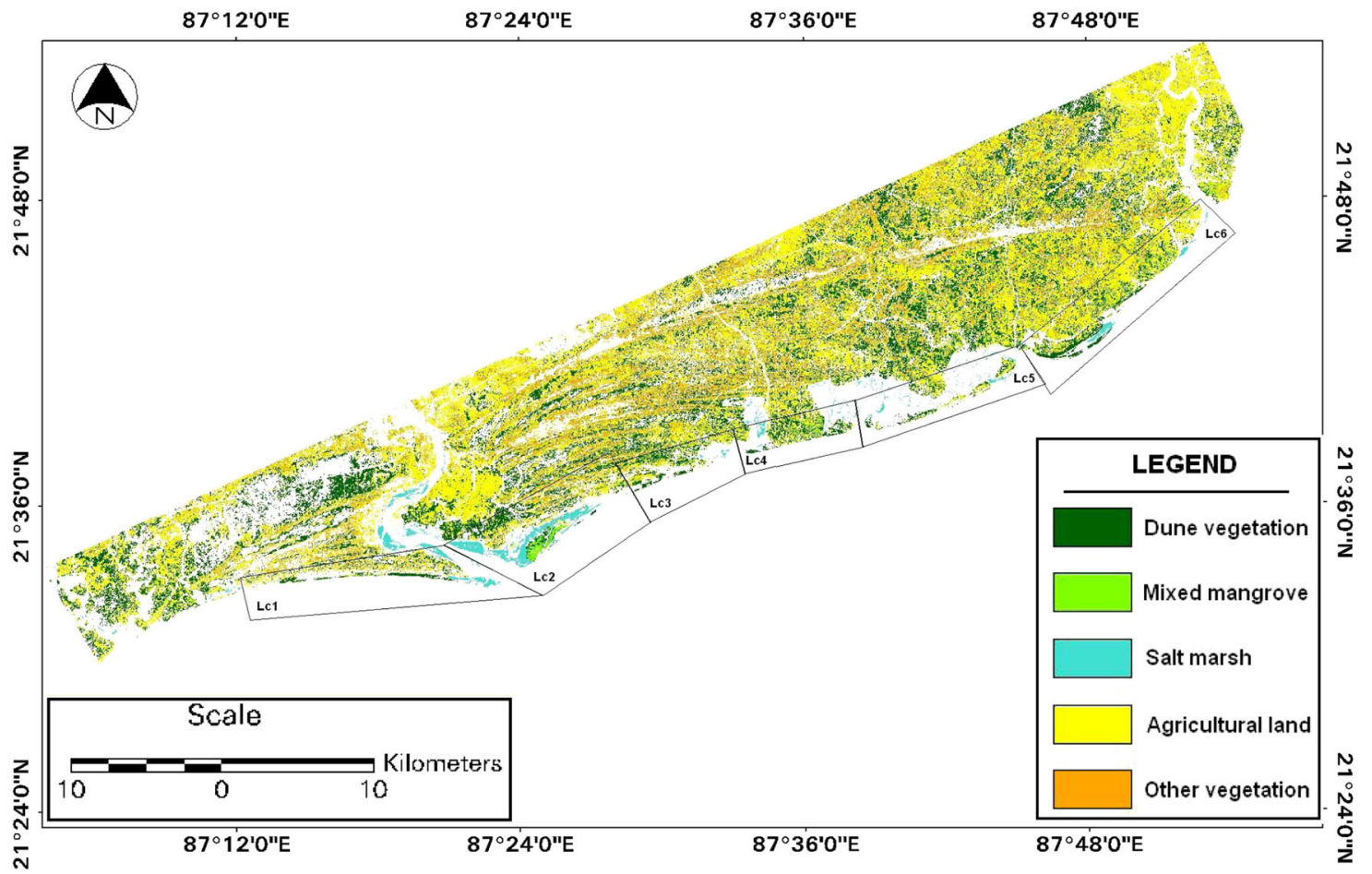

Fig. 8 Coastal vegetation map showing post-monsoon information of 2002

and samples of different species of coastal vegetation were collected using GPS, at various locations of the study area (Table 6).
Mangrove species like Avicennia sp. (black mangrove) and Rhizophora sp. (red mangrove) were found at Kakrapali (Subarnarekha estuary) and Talsari regions which was 
Table 3 Areal extent of dune vegetation in each littoral cells (area in ha)

\begin{tabular}{|c|c|c|c|c|c|c|c|}
\hline \multirow{2}{*}{$\begin{array}{l}\text { Littoral } \\
\text { cell (LC) }\end{array}$} & \multicolumn{2}{|l|}{2000} & \multicolumn{2}{|l|}{2001} & \multicolumn{2}{|l|}{2002} & \multirow{2}{*}{$\begin{array}{l}\text { Type of vegetation } \\
\text { observed in the field }\end{array}$} \\
\hline & Pre-monsoon & Post-monsoon & Pre-monsoon & Post-monsoon & Pre-monsoon & Post-monsoon & \\
\hline LC1 & 76.59 & 305.01 & 123.84 & 340.02 & 167.67 & 342 & $\begin{array}{l}\text { Casuarina equisetifolia, Pandanus } \\
\text { sp., Anacardium occidentale }\end{array}$ \\
\hline LC2 & 103.05 & 799.38 & 300.33 & 709.65 & 284.76 & 661.77 & No field observation \\
\hline LC3 & 109.17 & 501.3 & & 374.4 & 124.92 & 389.34 & No field observation \\
\hline LC4 & 124.74 & 329.04 & 213.75 & 311.49 & 204.39 & 407.43 & No field observation \\
\hline LC5 & 37.71 & 179.28 & 67.57 & 138.33 & 80.91 & 206.91 & $\begin{array}{l}\text { Casuarina equisetifolia, Ipomoea } \\
\text { biloba, Spinifex sp., Serenoa } \\
\text { repens }\end{array}$ \\
\hline LC6 & 247.86 & 903.96 & 246.15 & 585.54 & 334.26 & 845.55 & Casuarina equisetifolia \\
\hline
\end{tabular}

Table 4 Areal extent of mixed mangrove vegetation in each littoral cells (area in ha)

\begin{tabular}{|c|c|c|c|c|c|c|c|}
\hline \multirow{2}{*}{$\begin{array}{l}\text { Littoral } \\
\text { cell (LC) }\end{array}$} & \multicolumn{2}{|l|}{2000} & \multicolumn{2}{|l|}{2001} & \multicolumn{2}{|l|}{2002} & \multirow{2}{*}{$\begin{array}{l}\text { Type of vegetation observed } \\
\text { in the field }\end{array}$} \\
\hline & Pre-monsoon & Post-monsoon & Pre-monsoon & Post monsoon & Pre-monsoon & Post-monsoon & \\
\hline LC1 & 4.59 & 38.25 & 0.81 & 12.69 & 0.18 & 10.71 & Avicennia sp., Pandanus sp., \\
\hline LC2 & 176.85 & 228.33 & 201.69 & 209.88 & 167.94 & 73.62 & Avicennia sp., Rhizophora sp. \\
\hline LC3 & 20.16 & 65.43 & 5.22 & 30.78 & 3.6 & 14.31 & \\
\hline LC4 & 18.27 & 31.23 & 2.07 & 26.46 & 0 & 10.26 & \\
\hline LC5 & 4.68 & 13.14 & 0 & 13.5 & 1.17 & 7.11 & Pandanus sp. \\
\hline LC6 & 6.03 & 64.89 & 0.54 & 62.82 & 0.9 & 52.74 & \\
\hline
\end{tabular}

Table 5 Areal extent of salt marsh vegetation in each littoral cells (area in ha)

\begin{tabular}{|c|c|c|c|c|c|c|c|}
\hline \multirow{2}{*}{$\begin{array}{l}\text { Littoral } \\
\text { cell (LC) }\end{array}$} & \multicolumn{2}{|l|}{2000} & \multicolumn{2}{|l|}{2001} & \multicolumn{2}{|l|}{2002} & \multirow{2}{*}{$\begin{array}{l}\text { Type of coastal vegetation } \\
\text { observed in the field }\end{array}$} \\
\hline & Pre-monsoon & Post-monsoon & Pre-monsoon & Pre-monsoon & Post-monsoon & Pre-monsoon & \\
\hline LC1 & 69.93 & 44.19 & 23.22 & 74.52 & 139.5 & 166.23 & Salicornia sp., Portulaca sp., \\
\hline LC2 & 128.7 & 317.97 & 101.61 & 441.54 & 406.62 & 566.73 & \\
\hline LC3 & 3.51 & 25.02 & 30.96 & 21.24 & 9.81 & 22.59 & \\
\hline LC4 & 42.3 & 55.44 & 61.56 & 44.19 & 62.46 & 66.96 & \\
\hline LC5 & 98.55 & 143.19 & 99.63 & 103.68 & 181.89 & 128.25 & $\begin{array}{l}\text { Salicornia sp., Portulaca sp., } \\
\text { Spartina sp., Atriplex sp. }\end{array}$ \\
\hline LC6 & 19.98 & 81.45 & 56.97 & 82.26 & 15.66 & 116.55 & $\begin{array}{l}\text { Salicornia sp., Portulaca sp., } \\
\text { Spartina sp., Atriplex sp. }\end{array}$ \\
\hline
\end{tabular}

Table 6 Areal extent of the three main coastal vegetation (area in ha)

\begin{tabular}{llll}
\hline Vegetation types & Pre-monsoon-2000 & Post-monsoon-2002 & Change between two periods \\
\hline Mixed mangroves & 230.58 & 168.75 & -61.83 \\
Salt marsh & 362.97 & 1067.31 & +704.34 \\
Dune vegetation & 699.12 & 2853 & +2153.88 \\
\hline
\end{tabular}

Salt marshes comprise salt tolerant but not halophytic (salt-loving) genera. The low wave energy, high tidal range surplus of fine sediments are directly involve in the development of the plant community over tropical coast. 
Fig. 9 a Mangroves at Kankrapal. b Salt marsh vegetation at Junput. c Dune vegetation at Mandarmoni
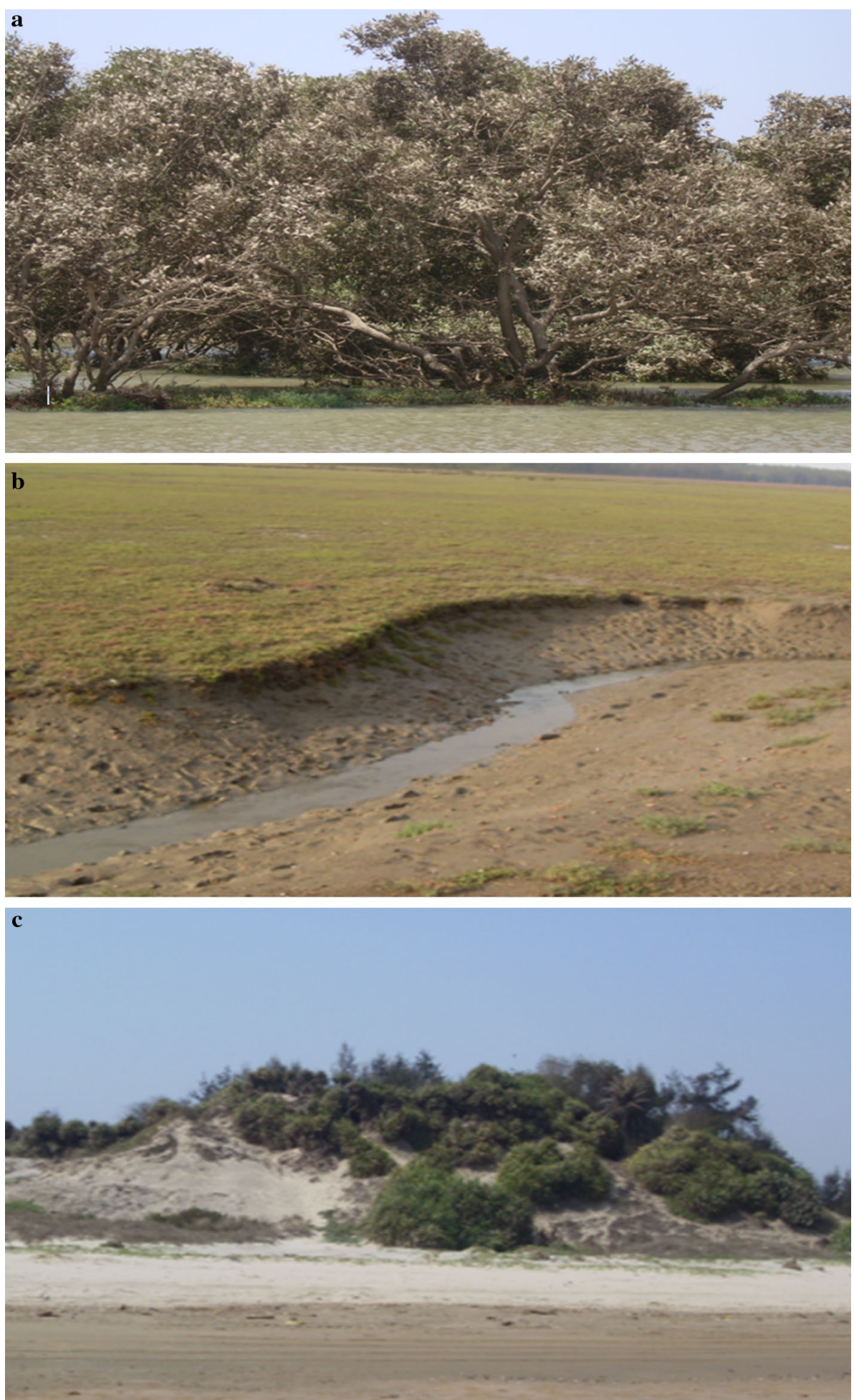

Several grasses, herbs and sedge plants of tidal flats are able to trap sediment, which lead the marsh surface to grow upward and seaward over time. Different types of salt marsh vegetation were observed in the intertidal areas of Rasulpur, Junput, Haripur, Purusottampur, Pichaboni and Dadanpatrabar (Fig. 9b). The higher marsh is dominated by
Salicornia sp., Suaeda sp., Sesuvium sp., Phragmites sp., (coarse grass) and Zoisia sp., and the lower marsh is colonized by pioneer species like Spartina $s p$. (salt-loving), Batis maritime, Porteresia, Aeluropus and Spinifex.

Dune vegetations like $C$. equisetifolia is a dominant species. Besides $C$. equisetifolia the other species are 
Accaccia, Aurecoliformis, Mangium (Akash moni), Tectoriu Soland (Keya), Pandanus sp., Serenoa repens, Sabal palmetto, Ipomoea biloba, Spinifex sp. Sand-loving grasses are found in all over the study area. Some special kind of sand-loving grasses like Ipomoea sp., Spinifex sp., growing on dunes were found at Dadanpatrabar and Mandarmoni (Fig. 9c).

There are three formations of plant succession from seaward to landward be observed along the study area. These are: Spinifex littoreus formation on the foreshore, I. biloba formation on mobile dunes and Casuarinas-ipomoea-Pandanus association on fixed dunes. Coastal plantation like Coconut, Cashew and Betel gardens on the beach ridges are included in the other coastal vegetations. The following vegetation on the aeolian sands is also included in this class: Saccharum sp., I. biloba, Pandanus sp., Calotropis sp., Zizyphus sp.

\section{Conclusion}

An estimate of spatial extent and monitor the health of coastal vegetation especially mangroves, salt marsh and the natural plants growing on sand dunes have been work out seasonally. The NDVI derived from ETM+ images provide useful information to monitor coastal vegetation changes. The analysis of NDVI variations showed the qualitative information about the vegetation. From the NDVI analysis, we can predict the health of the vegetation and the impact of environmental factors on it. Through the NDVI we can conclude that the health of the dune vegetation and mangroves increased in post-monsoon period and salt marsh become healthier in pre-monsoon period. On the other hand classified image provide quantitative information about the coastal vegetation. Rate of increasing or decreasing can be measured through the classified images. Through the supervised classification we can conclude that mangroves are decreases over the entire 3 years and salt marsh, dune vegetations have increases. Coastal vegetation plays a major role to protect the coastal region from erosion, coastal hazard. Among them $C$. equisetifolia and other two most important dune creepers $I$. biloba and Spinifex sp. helps in fixing the sand and protect the coastal dunes from erosion. The increasing rate in spatial extent of dune vegetation indicates that the coast will be more protective from erosion. Salt marsh provides a protected habitat for both marine and terrestrial organisms.
It is important for estuarine food chains; primary productivity and a support resource for estuarine food webs.

\section{References}

Beatley T, Brower DJ, Schwab AK (2002) Introduction to coastal zone management. Island press, Washington D.C, p 273

Campbell JB (2002) Introduction to remote sensing, 3rd edn. The Guilford Press, New York

Chatterjee B, Porwal MC, Hussin YA (2008) Assessment of tsunami damage to mangrove in India using remote sensing and GIS. The International Archives of the Photogrammetry, Remote Sensing and Spatial Information Sciences 2008, vol. XXXVII. Part B8, Beijing, pp 283-288

Dey S, Ghosh P, Nayak A (2005) The influences of natural environment upon the evolution of sand dunes in tropical environment along Midnapur coastal area India. Indones J Geogr 37(1):51-68

Fuller DO (1998) Trends in NDVI time series and their relation to rangeland and crop production in Senagal, 1987-1993. Int J Remote Sens 19(10):2013-2018

GSI (1995) Interim report on the coastal zone management of Digha planning area. Digha Development authority, Midnapur district, West Bengal, Geological Survey of India, Eastern region, pp 3-10

Hashiba H, Kameda K, Uesugi S, Tanaka S (2000) Landuse change analysis of Tama river basin with different spatial resolution sensor data by Landsat Mss and TM. Adv Space Res 26:1069-1073

Jana A, Biswas A, Maiti S, Bhattacharya AK (2014) Shoreline changes in response to sea level rise along digha coast, eastern india: an analytical approach of remote sensing, GIS and statistical techniques. J Coast Conserv 18:145-155. doi:10. 1007/s11852-013-0297-5

Lillesand TM, Kiefer RW (1994) Remote sensing and image interpretation, 3rd edn. Willey, New York

Lyon JG, Yuan D, Lunetta RS, Elvidge CD (1998) A change detection experiment using vegetation indices. Photogrammetric Engineering \& Remote Sensing 64(2):143-150

Maxwell SK, Schmidt GL, Storey JC (2007) A multi-scale segmentation approach to filling gaps in Landsat ETM + SLC-off images. Int J Remote Sens 28(23):5339-5356

Paul AK (2002) Coastal geomorphology and environment: sunadrban coastal plain, kanthi coastal plain, subarnarekha delta plain. ACB Publication, Kolkata

Reddy CS, Roy A (2008) Assessment of three decades vegetation dynamics in mangroves of Godavari Delta, India using multitemporal satellite data and GIS. Res J Environ Sci 2(2):108-115

Ricketts PJ (1992) Current approaches in geographic information systems for coastal management. Mar Pollut Bull 25:82-87

Sader SA, Winne JC (1992) RGB-NDVI colour composites for visualizing forest change dynamics. Int $\mathrm{J}$ Remote Sens 13(16):3055-3067 